\title{
THE IDENTIFICATION OF GEOSITES AS ELEMENTS OF GEOTOURISM OFFER IN KYSUCE REGION, SLOVAKIA
}

\author{
Pavel Hronček*, PhD., Pavol Rybár*, PhD., \\ Ľubomír Štrba*, PhD., Ladislav Hvizdák*, PhD., \\ Mário Molokáč*, PhD., Miloš Jesenský**, PhD. \\ *Institute of Earth Resources, Faculty of Mining, Ecology, Process Control and \\ Geotechnologies, Technical University of Košice, Letná 9, 04200 Košice, SK-Slovakia \\ **Museum of Kysuce in Čadca, Moyzesova 50, 022 OI Čadca, SI-Slovakia \\ e-mail: pavel.hroncek@tuke.sk, pavol.rybar@tuke.sk, lubomir.strba@tuke.sk, \\ ladislav.hvizdak@tuke.sk,mario.molokac@tuke.sk, jesensky@kysuckemuzeum.sk
}

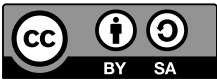

Professional article

COBISS 1.04

DOI: $10.4312 /$ dela.48.2.115-128

\begin{abstract}
The paper analyses the origin and evolution of the Kysuce landscape from the Mesozoic era until the arrival of humans, identifying the relics of these historical evolutionary stages in the present-day landscape. It presents the most important relics from individual evolutionary time horizons as significant elements of geotourism offer. They are systematised and analysed chronologically, thus allowing geotourists to gain a broader picture of the surveyed region, and bringing them into the focus of geotourists as tangible proof that even a landscape that was formed millions of years ago can continue to stimulate our interest. The paper provides information on authenticity and the opportunity for a potential visitor to "touch" the landscapes' millions-of-years-old relics in the area of the Kysuce region, Slovakia.
\end{abstract}

Keywords: geology, geomorphology, natural heritage, geotourism, geosite, Kysuce, Slovakia

\section{NARAVNE VREDNOTE KOT GRADNIKI RAZVOJA GEOTURIZMA: KYSUCE, SLOVAŠKA}

\section{Izvleček}

Prispevek se osredotoča na prepoznavanje razvojnega potenciala naravnih vrednot kot gradnikov geoturizma na severozahodu Slovaške (Kysuce). Naravne vrednote so predstavljene kot preostanki geološke in geomorfološke preteklosti v današnji pokrajini. 
Ključne naravne vrednote so kronološko sistematizirane in analizirane. Avtorji ugotavljajo, da je tovrstna pokrajina zaradi avtentičnosti in velike doživljajske zmožnosti izjemno zanimiva za geoturiste.

Ključne besede: geologija, geomorfologija, naravna dediščina, geoturizem, naravna vrednota, Kysuce, Slovaška

\section{INTRODUCTION}

The most advantageous sites for visiting the Earth's geological past are quarries and natural geological exposures, which provide tourists with a cross-section of the geological development on Earth millions of years ago. Such locations typically have information boards and often various educational routes, whilst their geotourism usage is rather determined by their location or proximity to other sites (Hronček, 2012).

In larger regions it may not be possible to link individual sites, although such sites are often quite unique and exceed regional significance. Today, thematic bike trails and educational bike paths to a certain extent resolve the problem of harder-to-access sites. A similar example can be found in the Kysuce region's (Slovakia), where numerous mineral sites, even of transnational importance, are declared as small scale protected areas (including protected sites, nature reserves and nature monuments). Such places are available for geotourism as solitary sites that indicate the geological development of a certain period.

The Kysuce area, as a historical region forming since the Early Modern Age (i.e. $16^{\text {th }}-17^{\text {th }}$ century), is located in the north-western part of Slovakia, on the border with the Czech Republic and Poland (Figure 1). Kysuce's geology is composed mostly of Cenozoic flysch rocks, whilst the landscape relief has been extensively shaped by the Kysuca River and its tributaries.

Figure 1: Location of the Kysuce region within Slovakia.

Slika 1: Lega preučevanega območja na Slovaškem.

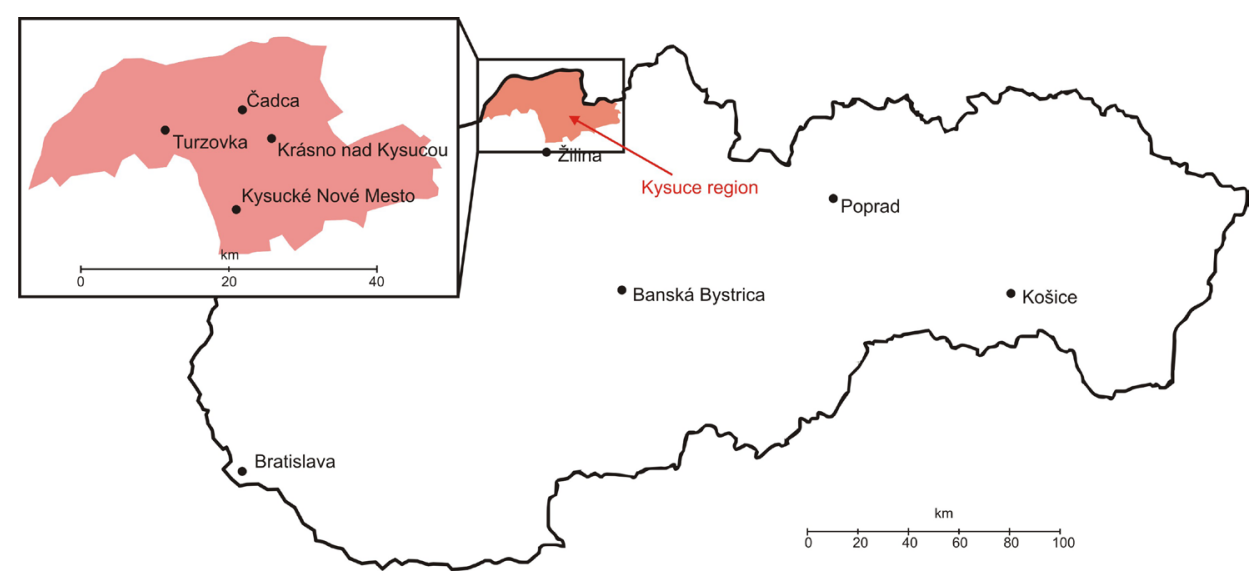


This paper aims: (1) to briefly analyse the origin and evolution of the Kysuce landscape from the Mesozoic Era until the arrival of humans, in order to identify the relics of these historical developmental stages in the present-day landscape; (2) to pinpoint the most important relics from the individual developmental time horizons and present them as significant geotourism sites - arranging them in chronological order will create a complete picture of the surveyed region; (3) to bring such landscape to the attention of geotourism-related studies as tangible proof that even a landscape that was formed millions of years ago can continue to stimulate our interest; and (4) to present the relics as potential geotourism targets in a way that a geotourist has an authentic idea about the correct chronological order of the landscape's formation and development, and can "touch" it.

\section{CONCEPT OF GEOTOURISM}

Geotourism as an independent branch of tourism has gained popularity only in recent years. In the 1990s, various nature-based tourism forms have been introduced. However, "ecotourism" and "sustainable tourism", instead of geotourism, were preferred, especially in the USA and Australia.

Modern geotourism has been defined for the first time in the late $20^{\text {th }}$ century by Thomas A. Hose, as an independent and, especially, a new form of tourism with evergrowing potential and interest of tourists. Hose (1995) defined geotourism as "the provision of interpretive and service facilities to enable tourists to acquire knowledge and understanding of the geology and geomorphology of a site (including its contribution to the development of the Earth sciences) beyond the level of mere aesthetic appreciation". Buckley (2003) saw little scope for geotourism as a separate type of tourism, but rather as a small, specialised part of ecotourism.

Geotourism in the broader sense was characterized by Joyce (2006) as a new branch of tourism in conjunction with geological and geomorphological sites and functions of individual sites or part of landscape. Therefore Joyce (2006) proposed a new definition of geotourism as a branch of tourism where "people are going to a place to look at and learn about one or more aspects of geology and geomorphology". The definition derives from the context of Australian nature, national parks and geoparks. Geotourism offers a deeper understanding of the landscape, geosites and their origin, and also provides a cultural experience in the landscape and teaches to see the landscape in a better way.

Lately several important works on geotourism were published (Dowling, Newsome, 2006; Dowling, 2009). Based on these publications, geotourism can be characterised as sustainable tourism with a primary focus on exploring the landscape in terms of geology, directed at the promotion of environmental and cultural understanding, appreciation and environmental protection for the benefit of a given site. Geotourism as a product protects, describes, promotes and markets geosites as part of our geological heritage - mainly natural sites.

Hose (2012) provided a revised definition of geotourism as "the provision of interpretative and service facilities for geosites and geomorphosites and their encompassing topography, together with their associated in-situ and ex-situ artefacts, to constituency-build 
for their conservation by generating appreciation, learning and research by and for current and future generations".

An alternative approach within the concept of geotourism is given by the National Geographic (2003) preferring geographical character of the area rather than geological features. In order to unify and clear the geotourism concept, Arouca Declaration (2011) combines both, geological and geographical approaches, arguing that geotourism is "tourism which sustains and enhances the identity of a territory, taking into consideration its geology, environment, culture, aesthetics, heritage and the well-being of its residents. Geological tourism is one of the multiple components of geotourism". But, as mentioned by Hose (2016), this definition fits more ecotourism rather than geotourism.

Moreover, in last years, intense research in the field of geotourism have brought definitions of various geotourism types, including underground geotourism (Garofano, Govoni, 2012), rural geotourism (Farsani et al., 2013), urban geotourism (Rodrigues et al., 2011; Ferreira et al., 2012), health and wellness geotourism (Farsani et al., 2013) or roadside geotourism (Štrba et al., 2016).

The application of relics in the context of geotourism is based on previously published papers dealing with this topic (e.g. Hose, 1999; Buckley, 2003; Schejbal, 2005; Dowling, Newsome, 2006; Joyce, 2006; Dowling, 2009; Rybár et al., 2010; Grecu, Iosif, 2014; Hronček, 2015; Kršić et al., 2015; Štrba, 2015).

\section{ORIGIN AND EVOLUTION OFTHE KYSUCE LANDSCAPE}

Until the Palaeogene Period, the geographical area of Kysuce was shaped by the same evolutionary processes as the rest of present-day Slovakia. At the end of the Mesozoic Era, an extensive Alpine developmental cycle began. The Triassic Period saw massive tectonic drops, and a large geosyncline (Tethys) was formed in the Western Carpathians. The Tethys Ocean covered all of future Kysuce as well as the whole territory of Slovakia. The marine environment experienced extensive carbon sedimentation during the Triassic and Jurassic Periods until the mid-Cretaceous, when the main Alpine stage mountain-forming processes began (130 million years ago). In the first stage, the Tethys geosyncline was folded in within 5-10 million years, and then the nappe series moved from north to south by tangential thrust. After major orogenic processes during the Cretaceous (145.5-65.5 million years), the Inner Western Carpathians became dry land, and a large deep-water trench formed on their outer arc and in the area of Kysuce (Fusán, 1972; Potfaj, 2003).

Vast amounts of material were washed into the sea from the adjacent mainland. The streams distributed the material evenly throughout the sea, creating excessive layers of sandstone as well as conglomerates alternating with layers of shales, called flysch. The flysch (from the German word fliessen, i. e. to flow), that today forms the underlying skeleton of the landscape of Kysuce, was formed in a marine environment on tectonically turbulent edges of continents (Hók, Kahan, Aubrecht, 2001). Further sedimentation took place in the oldest phase of the Paleocene. At the turn of the Eocene and Oligocene (approx. 34 million years ago) and in the Oligocene, there was still a very shallow tropical sea with a wide variety of marine life in the area of present-day Kysuce (Kvaček et al., 2006). When the 
phytoplankton in the seas died, they fell to the bottom of the shelf sea where complex geological processes turned it into natural gas and oil. A large number of Foraminifera (nummulites; Figure 2), molluscs, gastropods, bryozoans, crinoids, worms and urchins also lived in the sea. The waters were dominated by bony fish and sharks, and the first mammals appeared too - the precursors of today's whales. During the Savic phase of the Alpine folding, the flysch basin (the sea) started to gradually disappear. The sea retreated further north, and the whole flysch basin was lifted up and folded (Kováč et al., 2007; Kováčová et al., 2011).

Figure 2: Nummulites with diameter from 15 to $20 \mathrm{~mm}$ (photo: V. Paprčka).

Slika 2: Numuliti s premerom 15-20 mm (foto: V. Paprčka).

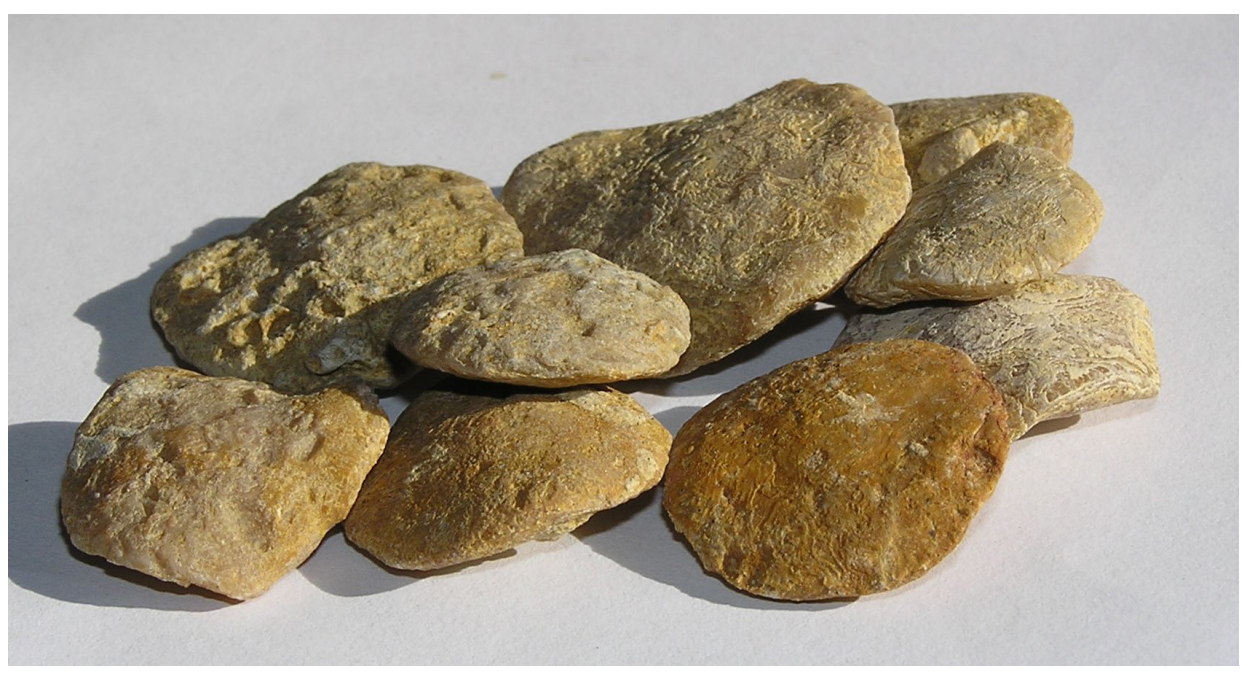

The geographical area of Kysuce definitely became mainland in the Early Miocene, approximately 20 million years ago. Massive, smoothly modelled flysch mountains formed that were much higher than today, and on their foothills in the north a new sedimentation zone sank (Kováč et al., 2007). The surface of what was to be Kysuce not only folded, but was also lifted up and became subject to denudation. The whole area was disrupted by a number of tectonic faults (Lukniš, 1972). With mainland being formed in the area of Kysuce, swamps with lush vegetation gradually appeared. Wetland habitats were characterised by the massive trees of the genus Taxodium and Cupressaceae, and sequoias in drier locations. At the end of the Tertiary Period, the wood from the huge trunks of these trees became the main material from which charcoal was formed. The marshes were inhabited by large numbers of amphibians, unicellular algae and diatoms (Špinar, 1988; Fejfar, 1989).

The southern part of the Kysuce area is formed by a narrow klippen belt that connects the External and Internal Western Carpathians. It has a complex geological and tectonic structure formed by Mesozoic rocks, various types of limestone from the Jurassic and Cretaceous period, and Paleogene marlites and flysch formations of the Tertiary. At the end of the Oligocene, orogenic activity in the area of the Western Carpathians continued 
with the Helvetic-Savic phase. It was accompanied by massive tangential pressure as well as extensive folding. During this phase, many narrow and compressed anticlines were formed. The heterogeneous foundation at the contact of two contrasting geological units did not fold evenly. The hard limestone cores of the anticlines behaved differently than their plastic, less resilient packaging that consisted of flysch rocks. The limestone rocks were substantially sturdier and could withstand more pressure, which tore them into blocks (limestone bodies) that created vast lenses in the flysch rocks. When they were pressed and folded more, these limestone lenses moved like raisins in dough (Mišík, 1976). Many of them, packed in much softer flysch sequences, got near the surface. At this time, the relief of the klippen belt was modelled quite smoothly by loaflike mountains. Cliffs protruded to the surface only rarely. What followed was a period of extensive erosion-denudation processes that gradually removed the less resistant flysch strata, forming individual cliffs. In the current klippen belt relief, two basic types of rocks can be distinguished. The klippen belt profile in Kysuce was created by the Kysuca River cutting into the individual sequences, creating cliffs in the southern part of the region.

After the Kysuce area was lifted up, the vast mountain plateau in the direction northwest- southwest was approx. $200 \mathrm{~km}$ wide and in the direction southwest-northeast 300 $\mathrm{km}$ long. The plateau protruded relatively steeply from the surrounding flat landscape situated at an altitude of up to $200 \mathrm{~m}$. The plateau itself was located at 1,200-1,400 m, and only rarely protruded higher (Kvaček et al., 2006).

From the Miocene, the relief of the Kysuce area started to be gradually formed by exogenous geomorphological factors, which has continued to the present time. The most significant relief-forming factor was flowing water, with the main relief skeleton of the Kysuce landscape being gradually shaped by the Kysuca River and its tributaries. The foundations of the Kysuca River network were laid in the early Miocene, during the Tortorian (11.6-7.2 mil. years). The river network in the basin of the Kysuca was based on fractures (Mazúr, 1963; Lukniš, 1972). From this period on, there was gradual erosion and denudation of the entire area. The foundations of smoothly modelled ridges were formed, divided by relatively shallow river valleys typical of the Kysuce flysch zone today.

During the Tertiary, the climate changed and evolved. In the younger Tertiary, the pleasant subtropical to tropical climate gradually deteriorated. The temperature and rainfall volume decreased. At the beginning of the younger Tertiary, the thermophilic vegetation (palms), forests and fauna retreated significantly southward, or disappeared from Europe completely. These changes took place during the younger Miocene, approx. 17 to 16 mil. years ago. Deciduous as well as coniferous forests became naturalised here (Kováčová et al., 2011; Kvaček et al., 2006). The species composition of the Tertiary forest was very similar to the current forest formations. These changes in the younger Tertiary were also accompanied by changes of fauna. Mammals had the most significant impact on the Tertiary fauna evolution. The first mammals lived in the Mesozoic Era, at the end of the lower Cretaceous (marsupials and insectivores). In the early Tertiary, they quickly spread, and during the Paleogene there were already about 400 mammal species. They quickly evolved, and at the end of the Tertiary the first human ancestors appeared (Holec, 2009; Špinar, 1988; Fejfar, 1989). 


\section{RELICS OFTHE PRE-QUATERNARY LANDSCAPE AS GEOTOURISM SITES}

The oldest preserved landscape elements include Mesozoic fossils in quarries in the southern, klippen part of Kysuce. In the quarries formed on the basis of Mesozoic limestones, the fossils of small marine animals have been preserved.

A special phenomenon in this connection is Kysucká brána (Figure 3), located about $15 \mathrm{~km}$ southwest from the confluence of the Kysuca and Bystrica. This significant geomorphological element forms a kind of imaginary gateway to Kysuce. Kysucká brána is formed by the Rochovica cliff ( $640 \mathrm{~m}$ above sea level) on the right side of the Kysuca valley close to the Javorníky mountains, and the Brodnianka cliff (720 m above sea level) on the left side of the Kysuca valley in the Kysuce Highlands. The structure of the Kysucká brána relief is formed by colourful Mesozoic layers of limestones, marlites, shales and, to a lesser extent, sandstones that underwent complex tectonic development during the forming of the klippen belt in the Paleogene (older Tertiary). At present, the whole area is formed by many separately exposed cliffs, especially in the adjacent part of the Kysuce Highlands. In the area of Kysucká brána, the Kysuca River cut deeply into the bedrock and modelled a characteristic narrow valley in the shape of a "gate". The lateral flow erosion created several outcrops of Mesozoic limestone strata that were enlarged and highlighted by quarrying in modern times.

Figure 3: Kysucká brána from the east (photo: P. Hronček).

Slika 3: Pogled na Kysucko brano z vzhodne strani (foto: P. Hronček).

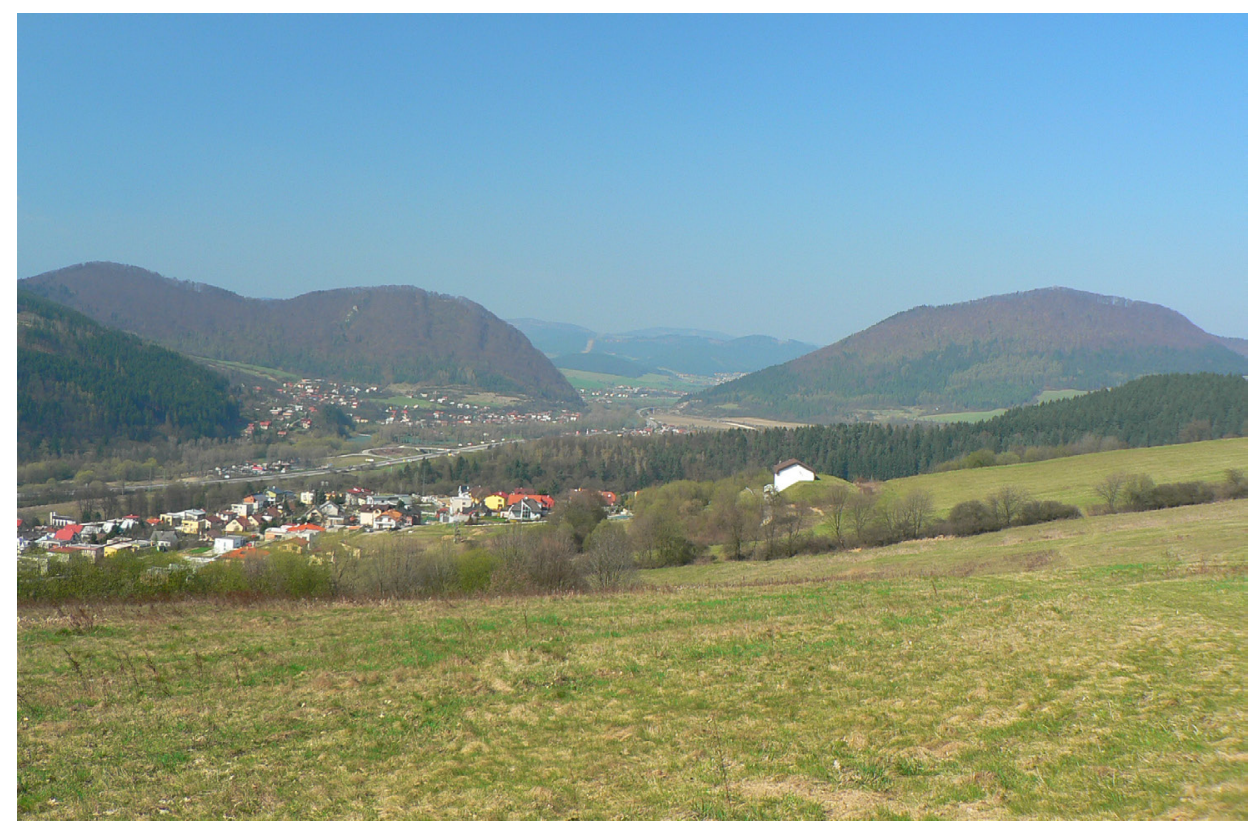


Table 1: Overview of the most significant geosites in the Kysuce region.

Preglednica 1: Najpomembnejše naravne vrednote na preučevanem območju (Kysuce, Slovaška).

\begin{tabular}{|l|l|l|}
\hline Location/Site & Age & Characteristics \\
\hline Kysucká brána & $\begin{array}{l}\text { Jurassic to } \\
\text { Paleogene }\end{array}$ & $\begin{array}{l}\text { fossils of Mesozoic organisms: Posiodnia alpina, } \\
\text { Radiolaria, Callpionellids, various remnants of } \\
\text { belemnites and ammonites }\end{array}$ \\
\hline Milošová-Megoňky quarry & $\begin{array}{l}\text { Cretaceous to } \\
\text { Middle Miocene }\end{array}$ & spherical rock separation \\
\hline $\begin{array}{l}\text { Stará Bystrica } \\
\text { (facade of the municipal office) }\end{array}$ & Eocene & fossils of Taphrhelminthopsis sp. \\
\hline Vychylovské prahy & Paleogene & exposure of exposed various resistant flysch layers \\
\hline Vel'ká Rača National Reserve & Tertiary & pseudokarst caves \\
\hline $\begin{array}{l}\text { Malý Polom National Natural } \\
\text { Reserve }\end{array}$ & Tertiary & spherical rock separation, flysch rock walls \\
\hline Nová Bystrica & $\begin{array}{l}\text { Tertiary to } \\
\text { Quaternary }\end{array}$ & stone sea \\
\hline Kornianský oil spring & Tertiary & $\begin{array}{l}\text { a naturally surfaced light oil spring with occasional } \\
\text { discharge of self-igniting methane }\end{array}$ \\
\hline
\end{tabular}

These strata include fossils of Mesozoic organisms that lived in the Jurassic and Cretaceous seas. There are imprints of the bivalve molluscs Posidonia alpina there, which evolved in the Paleozoic Era and became extinct in the Mesozoic, in the early Jurassic Period. The Jurassic layers typically include imprints of fossils of ammonite shells and microscopic residues of sponges and Radiolaria that build radiolarian limestones. In the layers from the turn of the Jurassic and Cretaceous Era, there are abundant remains of shells or just rocky cores and imprints of belemnites and ammonites. Under microscope, calpionellids (ciliates) can also be seen in these layers. In the lower Cretaceous layers of chert limestone, the black hornstones were used by people to make simple tools - arrow and spear heads, scrapers and primitive knives (Wetter, Bendík, 2009).

The Brodnianka cliff continues on the right side of the Snežnický stream in the Malý Vreteň cliff (653 m above sea level). On its southern slope is Snežnica quarry. In the limestone quarry, attractive ammonite fossils with a diameter of 10-13 cm can be found, which are among the most beautiful in the Kysuce region. Ammonites (Ammonoidea) were cephalopods that lived in large numbers in the Triassic, Jurassic and Cretaceous seas. Similar can be found on the neighbouring Malé Ostré cliff in the Lopušné pažitie limestone quarry, as well as in the Ochodnica and Klubina quarries.

The Tertiary flysch zone in Kysuce is mainly represented by the Zlín sandstone strata from the middle to upper Eocene, which stretches in a northern stripe from Makov to Čadca and in a southern stripe from Žilina to Osčadnica. Based on these rock structures, several quarries with local significance operated in the past (Pivko, 2010). Sandstones were used especially for building foundations and beddings under wooden cottages, as well as for building houses, public and administrative buildings, and churches. 
Complex tectonic development during the folding of the flysch layers is documented by an exposed slip fold, which was tilted by lateral pressures almost perpendicularly with its axis oriented to the south. This slip fold has been exposed at the construction site of the Čadca- Žilina road, southeast of Krásno nad Kysucou (Potfaj, 2003).

Probably the most important site from this period is the Milošová-Megoňky quarry, which is now protected as the Megonky Natural Monument (Hronček, 2012). This sandstone quarry with typical spherical rock separation is a world rarity. The abandoned quarry is approx. $40 \mathrm{~m}$ long and $30 \mathrm{~m}$ high, and located on the left of the Miklošovský stream valley in the Turzovka Highlands on the northern outskirts of Milošová village (site Vyšné Megonky, near to the settlement Padišákovci), about $200 \mathrm{~m}$ from the Czech border. The quarry wall, covered with vegetation, is divided into two main and three less pronounced levels. The quarry was opened due to flysch sandstone strata from the late Cretaceous to the middle Miocene, and sandstone was mined until the late 1980s. These sandstones are located on the tectonic contact line (point of overthrust) of the Magura unit (nappe) and the Silesian unit. The typical spherical rock separation can be found in a $15 \mathrm{~km}$ long area between Klokočov and Milošová (Potfaj, 2003). The stone formations vary from egg-shaped to perfectly spherical. There is also a large number of sphere imprints (sphere negatives) - the largest of which have a diameter of $5 \mathrm{~m}$. Most common are spheres with a radius of 90-110 cm and a weight of 9-15 t. This unique geological feature led to the quarry being declared a 1,670 $\mathrm{m}^{2}$ natural monument within the Protected Landscape Area Kysuce in 2003.

An interesting relic of the Tertiary landscape has also been preserved as a stone block set in the staircase facade of the Stará Bystrica municipal office. It is a fossil of the Taphrhelminthopsis sp. worm (Potfaj, 2003) from the Eocene. The stone was excavated from the Klubina sandstone quarry. Mining in the multi-level quarry started in 1983, and the excavated material was used to build the Stará Bystrica dam embankment.

A typical site representing the exposed various resistant flysch layers is Vychylovské prahy, currently protected as a natural monument. It was created by the Vychylovka stream, which stripped the edges of the slightly tilted layers through erosion. More resistant sandstones created pronounced benches (thresholds) up to $1 \mathrm{~m} \mathrm{high,} \mathrm{while} \mathrm{the} \mathrm{layers}$ of less resistant claystones were eroded. They are located in the Vychylovka stream bed under the settlement Pavelekovci, to the right of the access road from Nová Bystrica to Kysuce Village Museum. The bed is approx. $150 \mathrm{~m}$ long and up to $30 \mathrm{~m}$ wide. Along the thresholds, especially at the upper parts of the streams in the northern and southwestern part of Kysuce, interesting waterfalls created by the individual streams on varyingly resistant flysch layers can be found. The biggest is the $3 \mathrm{~m}$ high Klínsky waterfall, which is protected as a natural monument (according to the current Act No. 543/2002 Coll. on Nature and Landscape Protection 2002, waterfalls $3 \mathrm{~m}$ and higher are automatically protected as natural monuments). Other waterfalls (cascades) include e.g. Malopolomský waterfall (2.5 m), Horný Bukovský waterfall (2.5 m), Vychylovský waterfall (2.2 m) and Dolný Vychylovský waterfall $(1.7 \mathrm{~m})$. There are 14 waterfalls higher than $1 \mathrm{~m}$ in Kysuce (according to the list of Slovak waterfalls; Wikipedia, 2016).

The flysch area of the current landscape of Kysuce typically features relics of Tertiary sandstones in the form of rock walls and boulders, whether solitary or forming various 
clusters. One of the most interesting sites is the Vel'ká Rača National Reserve occupying the Vel'ká Rača massif (1,236 m above sea level) about $9 \mathrm{~km}$ northeast of the confluence of the Kysuca and Bystrica Rivers on the border with Poland. There are two pseudokarst caves here: Vel'ká skalná diera (22 m long) and Malá skalná diera ( $9 \mathrm{~m} \mathrm{long),} \mathrm{created} \mathrm{by}$ selective weathering and subsequent erosion of the Tertiary layers of alternating sandstone and claystone. The cave was created by the weathering of less resistant claystone. These are the only pseudokarst caves in the Kysuce region (Beleš, 2006).

The selective weathering of varyingly resistant layers of Tertiary flysch also created pronounced morphological elements of the contemporary landscape - stone walls, formed by the fronts of folds with lengths of $500 \mathrm{~m}$ and a height of 2-20 m. The most significant and protected are rock walls in the Malý Polom National Nature Reserve with a length of $500 \mathrm{~m}$, as well as the rock wall in the Klokočovské skálie Nature Reserve with a length of $300 \mathrm{~m}$ and spherical rock separation. Both are located in the administrative area of Klokočov. Rock walls have also been preserved in the klippen belt as an exposed relic after the folding of limestone rocks. The most beautiful rock wall is protected as the Vel'ké Ostré Natural Monument in the administrative area of Radol'a village.

The long-term influence of weathering processes in combination with gravity processes created extensive planar accumulations of stone blocks on the slopes of the rock walls and rock massifs - stone seas. The most significant stone sea in Kysuce is situated in the administrative area of Nová Bystrica on an area of 2 ha (approx. $800 \mathrm{~m}$ long and 20-40 m wide). The accumulated sandstone blocks are protected as the Vychylovské skálie Natural Monument (Belěs, 2006).

Preserved exposed rock solitaries of Tertiary sandstone include Jánošíkove skaly on the boundary of the cadastral area, Dlhé Pole and Turzovka, Skala odsúdencov in the massif of Vel'ký Polom near the border with the Czech Republic, Garne or Hadia hlava, Medvedia skala in Raková, Kuboškova skala, Tornekova skala and Skól'e in Klokočov, and rocks under Biely Kríž.

Due to the massive Tertiary, Oligocene denudation and following sedimentation of freshwater marshes, the lush vegetation that fell into the water was covered by sediment layers before it could decompose. Over millions of years it turned into layers of coal. Likewise, the remains of marine organisms were transformed into natural gas or oil. The Oligocene coal seam does not protrude to the surface. Coal around Svrčinovec was surveyed especially at the beginning of the $20^{\text {th }}$ Century (Kandera, Šlepecký, Potfaj, 2003), with two deep wells drilled in the villages of Turzovka and Svrčinovec (Jahn, 1909). Drilling in the Šl'ahorov stream began in September 1913 (Kandera, Šlepecký, Potfaj, 2003). One of the wells reached a depth of 1,155.60 m, making it the second deepest well in Slovakia after Šariš $(1,200 \mathrm{~m})$.

The situation in connection with oil was different, as it had been known in Kysuce since time immemorial due to several natural surface seepages around Korna (Lende, Stračánek, 1936), where drilling began in 1900 with the T-I drill (Milička, Macek, 2012) reaching a depth of $702.6 \mathrm{~m}$. It found strong evidence of oil and natural gas at a depth of 103-117 $\mathrm{m}$ in a sand layer (Posewitz, 1906). It now has a key place in the landscape of Kysuce. Based on historic records of the well position, the Kornianský oil spring is most 
probably the oil seepage from this old well (Milička, Macek, 2012). Oil extraction ended in spring 1933: despite the high oil quality in Kysuce, extraction was unprofitable because of the low yield (Kysucké hlasy, 1933).

\section{CONCLUSIONS}

The analysed sites constitute an important sample of major geosites in the Kysuce region in the northwestern part of Slovakia. The region apparently does not have the potential to create a geopark as such, but the individual sites and landscape elements representing the landscape relics form an interesting network of geosites. Under this term, we understand such landscape elements that constitute geological heritage of a limited size (Rybár, Baláž, Štrba, 2010). They represent a mosaic of sites of special geological significance of the given area, its geological history, events, phenomena and processes. They contribute to the conservation of significant geological features that provide information in various geoscience disciplines. They secure facilities for research and sustainable development at the local and regional level, and provide opportunities for geological and ecological education. The inclusion of these geo-objects in the geosite network of Kysuce now only requires formal acts, such as the processing of basic data for individual geosites: name, geographic location, geographic coordinates, characteristics of the place, and information on whether the site represents a precise chronostratigraphic units representing specific time of the Earth's history. The inclusion of individual sites in the geosite network and the diversity and uniqueness thereof would increase the geotourism potential of the Kysuce region.

\section{References}

Act No. 543/2002 Coll. on Nature and Landscape [Zákon o ochrane prírody a krajiny]. 2002. URL: http://www.zakonypreludi.sk/zz/2002-543 (accessed 10.10.2015).

Arouca Declaration 2011. URL: https:/dl.dropboxusercontent.com/u/36358978/News/ Declaration_Arouca_\%5BEN\%5D.pdf (accessed 10.10.2015).

Beleš, F., 2006. Rozmanitost' javov neživej prírody na Kysuciach. Enviromagazín, 2006, 3, pp. 10-12.

Buckley, R., 2003. Environmental Inputs and Outputs in Ecotourism: Geotourism with a Positive Triple Bottom Line? Journal of Ecotourism, 2, 1, pp. 76-82.

Dowling, R. K., 2009. The growth of global geotourism. In: Neto de Carvalho, C., Rodrigues, J. (ed.). New Challenges with geotourism, Proceedings of the VIII European Geoparks Conference, 4-6 September 2009, Portugal, pp. 24-30.

Dowling, R. K., Newsome, D., 2006. Geotourism's issues and challenges. In: Dowling, R. K., Newsome, D. (ed.). Geotourism: Sustainabillity, impacts and management. Oxford, UK, Elseviere Ltd., pp. 242-254.

Farsani, N. T., Coelho, C.O.A., Costa, C.M.M., 2013. Rural geotourism: A new tourism product. Acta Geotouristica, 4, 2, pp. 1-10.

Fejfar, O., 1989. Zkamenělá minulost. Praha, Albatros, 304 pp. 
Ferreira, M., Sá Caetano, P., Patuleia, M., 2012. Below and above the surface: urban geotourism on the Lisabon underground public transportation. Revista Turismo e Desenvolvimento, 17/18, pp. 345-352.

Fusán, O., 1972. Geológia. In: Lukniš, M. (ed.). Slovensko - príroda. Bratislava, Obzor, pp. 19-123.

Garofano, M., Govoni, D., 2012. Underground geotourism: a historic and economic overview of show caves and show mines in Italy. Geoheritage, 4, pp. 79-92. DOI: 10.1007/s12371-012-0055-3.

Grecu, F., Iosif, D., 2014. The geosites from Danube defile in Romania. The vulnerability to touristic activities. GeoJournal of Tourism and Geosites, 14, 2, pp. 178-184.

Holec, P., 2009. Paleontológia, kreacionizmus a evolúcia. URL: http://www.uski.sk/ frm_2009/ran/2003/ran-2003-1-04.pdf (accessed 12.10.2015).

Hók, J., Kahan, Š., Aubrecht, R., 2001. Geológia Slovenska. Bratislava, UK, 48 pp.

Hose, T. A., 1995. Selling the story of Britain's stone. Environmental interpretation, 10, 2, pp. 16-17.

Hose, T. A., 1999. Geology and tourism. The Buckinghamshire College, High Wycombe, pp. 1-32.

Hose, T. A., 2012. 3G's for modern geotourism. Geoheritage, 4, pp. 7-24. DOI: 10.1007/ s12371-011-0052-y.

Hose, T. A., 2016. Three centuries (1670-1970) of appreciating physical landscapes. In: Hose T. A. (ed.). Appreciating physical landscapes: Three hundred years of geotourism. London, The Geological Society, pp. 1-23. DOI: 10.1144/SP417.15.

Hronček, P., 2012. Možnosti využitie lomov v geoturizme [Possibilities of Quarries in Geotourism]. Geografická revue, 8, 2, pp. 5-113.

Hronček, P., 2015. Local quarries and how to use them in geotourism. Acta Geoturistica, 6, 1, pp. 11-20.

Jahn, J., 1909. Pokračuje-li karbon ostravsko-karvínsky pod Karpaty. Živa - časopis př́rodovědecký, 20, 4, pp. 112.

Joyce, E. B., 2006. Geomorphological Sites and the new Geotourism in Australia. Melbourne, School of Earth Sciences, The University of Melbourne, 25 pp.

Kandera, K., Šlepecký, T., Potfaj, M., 2003. Prehl'ad ložísk regiónu. In: Potfaj, M. (ed.). Vysvetlivky ku geologickej mape regiónu Kysuce. Bratislava, Štátny geologický ústav D. Štúra, pp. 96-100.

Kováč, M., Andreyeva-Grigorovich, A., Bajraktarevic, Z., Brzobohaty, R., Filipescu, S., Fodor, L., Harzhauser M., Nagymarosy, A., Oszczypko, N., Pavelico, D., Rogl, F., Saftico, B., Sliva, L., Studencka, B., 2007. Badenian evolution of the Central Paratethys Sea: paleogeography, climate and eustatic sea-level changes. Geologica Carpathica, 58, 6, pp. 579-606.

Kováčová, M., Doláková, N., Kováč, M., 2011. Miocene vegetation pattern and climate change in the northwestern Central Paratethys domain (Czech and Slovak Republic). Gelogica Carpathica, 62, 3, pp. 251-266.

Kršić, A., Misilo, M., Musa, S., 2015. Geotourism as a factor of development of Mid-Bosnian Schist Mountains area (example of Fojnica municipality). Dela, 43, pp. 109-122. 
Kvaček, Z., Kováč, M., Kovareder, J., Doláková, N., Jechorek, H., Parashiv, V., Kováčová, M., Sliva, L., 2006. Miocene evolution of landscape and vegetation in the Central Paratethys. Geologica Carpathica, 57, 4, pp. 295-310.

Kysucké hlasy, 4 June 1933, VII, 10, p. 2.

Lende, G., Stračánek, J., 1936. Dobývanie nafty na Slovensku. In: Sborník Spojeného banského revíru pre Slovensko a Podkarpatskú Rus. Volume I. Bratislava, pp. 375-408.

Lukniš, M., 1972. Reliéf. In: Lukniš, M. (ed.). Slovensko - príroda. Bratislava, Obzor, pp. 124-202.

Mazúr, E., 1963. Žilinská kotlina a pril'ahlé pohoria. Bratislava, SAV, 186 pp.

Milička, J., Macek, J., 2012. Historical and geochemical outlines of the oil-gas seepage near Turzovka town; Flysch belt, NW Slovakia. Acta Geologica Slovaca, 4, 1, pp. 7-13.

Mišík, M., 1976. Geologické exkurzie po Slovensku. Bratislava, SPN, 276 pp.

National Geographic. 2003. About Geotourism. URL: http://ravel.nationalgeographic. com/travel/sustainable/pdf/about-geotourism.pdf (accessed 08.10.2015).

Pivko, D., 2010. Významné horniny používané ako opracované kamene v historických pamiatkach Slovenska. Mineralia Slovaca, 42, pp. 241-248.

Posewitz, T., 1906. Petroleum és aszfalt Magyarországon. A Magyar Királyi Földtani intézet évkönyve, XV/4., Budapest. Franklin-társulat könyvnyomdája, 243 pp.

Potfaj, M., (ed.) 2003. Vysvetlivky ku geologickej mape regiónu Kysuce. Bratislava, Štátny geologický ústav D. Štúra, 193 pp.

Potfaj, M., 2003. Geologický vývoj územia. In: Potfaj, M. (ed.). Vysvetlivky ku geologickej mape regiónu Kysuce. Bratislava, Štátny geologický ústav D. Štúra, pp. 104-105.

Rodrigues, M. L., Machado, C. R., Freire E., 2011. Geotourism routes in urban areas: a preliminary approach to the Lisbon geoheritage survey. Geojournal of tourism and geosites, 8, 2, pp. 281-294.

Rybár, P., Baláž, B., Štrba, L., 2010. Geoturizmus - identifikácia objektov geoturizmu. Košice, Fakulta BERG, TU Košice, 101 pp.

Rybár, P., Hvizdák, L., Molokáč, M., Hvizdáková, J., 2010. Information technologies in montaneous tourism. Acta geoturistica, 1, 2, pp. 41-49.

Schejbal, C., 2005. Geoturizmus. Košice, Fakulta BERG, TU Košice, 110 pp.

Špinar, V.Z., 1988. Kniha o pravěku. Praha, Albatros, 252 pp.

Štrba, L., 2015. Identification and evaluation of geosites along existing tourist trail as a primary step of geotourism development: Case study from the Spiš region (Slovakia). GeoJournal of tourism and geosites, 16, 2, pp. 127-141.

Štrba, L., Baláž, B., Lukáč, L., 2016. Roadside geotourism - an alternative approach to geotourism. e-Review of tourism research, 13, 5/6, pp. 598-609.

Wetter, R., Bendík, A., 2009. Brodno - Kysucká Brána. In: Jeleň, S., Galvánek, J. (ur.). Náučno-poznávací sprievodca po geologických a geografických lokalitách stredného Slovenska. Geologický ústav Slovenskej akadémie vied, Banská Bystrica, príloha: 1 CD-ROM, pp. 41-42.

Wikipedia. Zoznam vodopádov na Slovensku. 2016. URL: https://sk.wikipedia.org/wiki/ Zoznam_vodopádov_na_Slovensku\#CHKO_Kysuce (accessed 10.03.2016). 


\section{NARAVNE VREDNOTE KOT GRADNIKI RAZVOJA GEOTURIZMA: KYSUCE, SLOVAŠKA}

\section{Povzetek}

Geološka, geomorfološka in naravna dediščina so sestavni gradniki geoturizma. Naravne vednote, ki so v ospredju tovrstne turistične ponudbe, so običajno v pokrajini razpršene. Prispevek se osredotoča na dejstvo, da je potrebno geoturistu priskrbeti celovito in strokovno argumentirano informacijo o naravnih vrednotah. Zato so avtorji na severozahodu Slovaške (Kysuce) opravili obsežno analizo, v kateri so prepoznali, sistematizirali in datirali ključne naravne vrednote, ki bi jih bilo smiselno vključiti v geoturistično ponudbo. Analiza je pokazala, da preučevano območje nima potenciala za ustanovitev samostojnega geoparka. Obstoječe naravne vrednote imajo pomembno raziskovalno in izobraževalno funkcijo. Prepoznane naravne vrednote bi bilo smiselno povezati v mrežo, kar obstoječa zakonodaja tudi omogoča. Za vsako naravno vrednoto bo potrebno priskrbeti osnovne informacije, tj. ime, geografsko lokacijo, geografske koordinate, značilnosti naravne vrednote, in jo umestiti v časovni prikaz geološkega razvoja Zemlje. Tako oblikovana ponudba bi lahko povečala geoturistični potencial preučevanega območja.

(V slovenski jezik prevedla Irma Potočnik Slavič) 